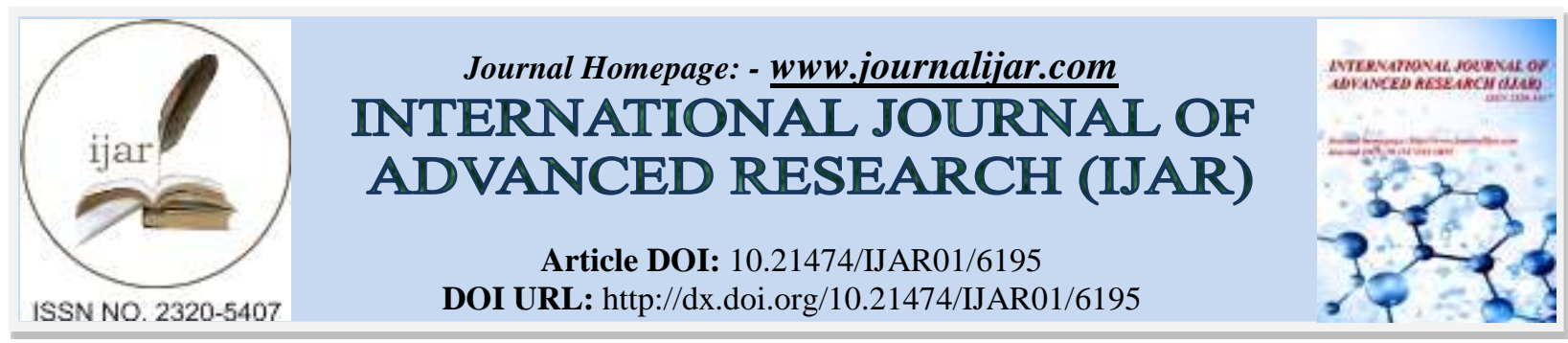

RESEARCH ARTICLE

\title{
ESSENTIAL OIL FROM THE AERIAL ROOTS OF FICUS ELASTICA AND THEIR ANTIOXIDANT ACTIVITY.
}

\section{Zafar iqbal $^{1}$, Afifa saeed ${ }^{2}$, Marvi mansha ${ }^{2}$, Khalid Saeed $^{3}$, Sehar Afzal $^{4}$, Hafiza iqra Khalil ${ }^{2}, Z_{\text {Zubia gulzar }}^{2}$ and Zaheen tara ${ }^{2}$.}

1. Applied Chemistry Research Centre, PCSIR Laboratories Complex, Lahore-54000-Pakistan.

2. Department of Chemistry, Govt. Post Graduate Islamia College (W), Cooper Road, Pakistan.

3. FBRC, PCSIR Laboratories Complex, Lahore-54000-Pakistan.

4. University of Veterinary and Animal Sciences, Lahore.

\section{Manuscript Info}

\section{Manuscript History}

Received: 03 November 2017

Final Accepted: 05 December 2017

Published: January 2018

Keywords:-

Aerial roots, Ficus elastica, Essential oil, GC-MS, Chemical Constituents, Antioxidant.

\section{Abstract}

Essential oil of aerial roots of Ficus elastica was extracted through hydro-distillation followed by separation by diethyl ether and dried over anhydrous sodium sulfate. Gas chromatography-mass spectrometry study of essential oil was performed to determine its chemical constituents. Fifteen constituents were identified and major constituents were benzene, [1-methyldodecyl] $(9.96 \%)$; benzene, [1ethynundecyl] (14.14\%); 3,9 $\beta, 14,15$-di-epoxypregn-16-en-20-one $(15.72 \%) ; \quad$ benzene,[1-propyldecyl] $\quad(5.24 \%)$; $\quad 9,12,15-$ octadecatrienoicacid (6.76\%); 2,3 bis[trimethylsilyl] 1-oxylpropylester (12.44\%); 9,12,15-octadecatrienoic acid,2,3-bis[trimethylsilyl-oxy propylester (7.13\%); octadec-9-enoic acid icosyl ester (7.07\%) respectively. The antioxidant activity of the essential oil was measured by using DPPH and ascorbic acid as standard. The maximum antioxidant activity of the essential oil was $61.01 \%$ with $100 \mathrm{mg} / \mathrm{ml}$ while the antioxidant activity of ascorbic acid with similar concentration was $100 \%$. Antioxidant prevents free radical induced tissue damage by preventing the formation of radicals, scavenging them, or by promoting their decomposition. Antioxidants obtained from natural resources are better for human health as they are less harmful.

Copy Right, IJAR, 2018,. All rights reserved.

\section{Introduction:-}

Ficus elastica belongs to the family Moraceae commonly known as the rubber fig, rubber bush, rubber tree, or Indian rubber bush. It is a widely-spread evergreen tree up to $30 \mathrm{~m}$ tall, having thick and dark green 7-20 cm long leaves with smooth edges and pointless tips. ${ }^{\text {i }}$ Ficus elastica is belongs to genus ficus which has about 2000 varieties and 800 species $^{\mathrm{ii}}$.In Egypt, many ficus species are found in streets, gardens, parks and outside the canal banks. The fruits of two ficus species are eatable by Egyptian peoples iii $^{\text {ii }}$ Rubber plants are not produce highly colorful or fragrant flowers for the attraction of other pollinators ${ }^{\text {iv }}$. Ficus has most commonly species which is called ficus carica $L$ has a fruit known as Fig which is a commercial fruit ${ }^{v}$. 
The white latex obtained from the bark of ficus elastica is used to prepare rubber. It is also used in medicine such as to cure the skin infection, allergies, anemia, and neurodegenerative disorder and hepatic problems; and also used as diuretic agent ${ }^{\mathrm{vi}}$. Herbalism is a traditional or also known as folk medicine extract from plants ${ }^{\mathrm{vii}}$. They have used in medicine as astringents, carminatives, stomachics, vermonicides, and anti-dysentery drugs ${ }^{\text {viii }}$. Ficus plants are also used not only in the treatment of cancer but in various diseases ${ }^{\text {ix }}$. Ficus elastica Roxb.and Ficus bengalensis Linn. are anti-flammatory and analgesic ${ }^{\mathrm{x}}$.

There is merely a report on Ficus elastica leaves, but not only a single report on the aerial roots in the literature. So, the current study was designed to investigate the chemical constituents of essential oil and its antioxidant activity. Most of the diseases are due to the oxidative stress, free radicals ${ }^{x i}$.these free radicals are the basic part of any biochemical process and shows an essential part if aerobic life and metabolism ${ }^{\text {xii }}$. Free radicals are adversely changed the lipids, proteins and DNA and large number of human diseases ${ }^{\text {xiii }}$. The essential oils are used as fragrance in perfumes and aromas in food industry ${ }^{\text {xiv }}$. These essential oils have number of biological activities, like antibacterial, antifungal and antioxidant properties ${ }^{\mathrm{xv}}$.

\section{Materials and Methods:- \\ Collection of Plant material:-}

The plant sample (aerial roots) was collected from the PCSIR (Pakistan Council of Scientific and Industrial Research) on 20 December 2016 in Lahore Pakistan. The aerial roots were cut into small pieces, extraction of essential oil was carried out by hydro-distillation in the oil and fat research laboratory.

\section{Reagents:-}

All the chemicals (diethyl ether, sodium sulfate anhydrous, DPPH, used were standard and of analytical grade.

\section{Extraction of essential oil:-}

The aerial roots was collected and then cut into small pieces and essential oil was extracted through hydrodistillation by using Dean Stark apparatus. Top hazy layer was obtained and separation was carried out by using diethyl ether in a separating funnel. Organic combined layer was dried over sodium sulfate anhydrous and essential oil was stored in a well tight closed bottle in refrigerator for GC-MS and antioxidant studies.

\section{GC-MS analysis of essential oil of aerial roots of ficus elastica:-}

Essential oil extracted from the aerial roots of ficus elastica was analyzed for its chemical constituents by gas chormatograph coupled with mass spectrometery (GC-MS). Agilant 5973-6890 gas chromatograph-mass spectrometry system, operating in EI mode at $70 \mathrm{ev}$ equipped with a split-splitless injector was used. Helium was used as a carrier gas at the flow rate of $1 \mathrm{ml} / \mathrm{min}$, while HP-5MS $(30 \mathrm{~m}, 0.25 \mathrm{~mm}, 0.25 \mathrm{um})$ capillary column was used. The initial temperature was programmed at $50-100{ }^{\circ} \mathrm{C}$ at the rate of $5{ }^{\circ} \mathrm{C} / \mathrm{min}$ and then $100-250{ }^{\circ} \mathrm{C}$ at the rate of $3{ }^{\circ} \mathrm{C} / \mathrm{min}$ followed by a constant temperature at $260^{\circ} \mathrm{C}$ for a period of 20 minutes. Sample $(2 \mu \mathrm{l})$ was injected to the column programmed at $200{ }^{\circ} \mathrm{C}$ and resolution of components was attained. Identification of components was performed by matching their retention indices and mass spectra with those obtained the NIST library.

\section{Antioxidant activity of essential oil of aerial roots of Ficus elastic:-}

Antioxidant activity of the essential oil of aerial roots of ficus elastica was evaluated by the scavenging activity of DPPH (2, 2-Diphenyl-1-picrylhydrazyl) radical. The DPPH assay was performed by following the method of Epsin et al. $(2000)^{\mathrm{xvi}}$. $0.1 \mathrm{mM}$ DPPH solution was prepared by dissolving $1 \mathrm{mg}$ of DPPH in $60 \mathrm{ml}$ of methanol. Different concentration $20,40,60,80$ and $100 \mu \mathrm{L}$ of plant extract took in test tubes; add $30 \mathrm{ml}$ of reagent in every test tube ranging R1, R2, R3, R4 and R5. The reaction mixture was incubated in dark condition at room temperature for about 30 minutes. For each samples three replicates were recorded. The disappearance of the DPPH was measured spectro-photometrically at $517 \mathrm{~nm}$. The percentage scavenging of DPPH by the extract was calculated by the following equation.

Where

$$
\% \text { DPPH Radical scavenging effect }=\left[\frac{(A c-A s)}{A s}\right] \times 100
$$

$A c$ is the absorption of the control at 30 minutes.

$A s$ is the absorbance of the sample at 30 minute 


\section{Results and Discussion:-}

The essential oil extracted from the aerial roots of ficus elastica was slight yellowish in color and its yield was $0.02 \%$. Their chemical constituents were analyzed by GC-MS. Agilant 5973-6890 gas chromatography-mass spectrometry system, operating in EI mode at 70ev equipped with a split-split injector was used. Fifteen constituents were identified in the essential oil of Ficus elastica aerial roots (table 1). Benzene, [1-propyldecyl], benzene, [1propylheptadecyl], 6-monoacetylmorohine, benzene, [1-ethylundecyl], propanamide, N, N-didecyl-3-phenyl, benzene, [1-methyldodecyl], diethyl Phthalate, octadecane, 3-ethyl-5-[2-ethylbutyl], cyclopropanebutanoic acid,2||2-||2-|[2-pentylcyclopropyl]methylcyclopropylmethylcyclopropylmethyl-methyl ester, propanoic acid, 2-[3acetotoxy-4,4,1,] 4-trimethylandrost-8-en-17-yl], 3,9 $\quad \beta ; 14,15$-Diepoxypregn-16-en-20-one,3.11 $\beta, 18$-triacetoxy, 9,12,15-octadecatrienoicacid,2,3bis[trimethylsilyl]1-oxylpropylester, [Z,Z,Z], oleic acid, eicosylester, propanoic acid, 2-[3-acetoxy-4,4,] 4-trimethylandrost-8-en-17-yl and D-glucose,6-o- $\alpha$-D-galactopyranosyl, bis-o[trimethylsilyl] derive.., cyclo tris[methylboronate] with relative abundance $9.96 \%, 4.96 \%, 0.83 \%, 14.14 \%, 1.42 \%$, $15.72 \%, 5.24 \%, 3.25 \%, 2.96 \%, 6.76 \%, 12.445,7.13 \%, 7.07 \%$ and $4.42 \%$ respectively.

Table 1:- Chemical constituents of essential oil from the aerial roots of ficus elastica.

\begin{tabular}{|c|c|c|c|}
\hline $\begin{array}{c}\text { Peak } \\
\#\end{array}$ & Compound & $\begin{array}{l}\text { Retention } \\
\text { Time } \\
\text { (Minute) }\end{array}$ & $\begin{array}{c}\text { Relative } \\
\text { abundance } \\
\text { (\%age) }\end{array}$ \\
\hline 1 & Benzene,[1-propyldecyl] & 8.79 & 9.96 \\
\hline 2 & Benzene,[1-propylheptadecyl] & 9.01 & 4.96 \\
\hline 3 & 6-Monoacetylmorphine & 9.58 & 0.83 \\
\hline 4 & Benzene,[1-ethylundecyl] & 11.74 & 14.14 \\
\hline 5 & Propanamide, N, N-didecyl-3-phenyl & 13.14 & 1.42 \\
\hline 6 & Benzene,[1-methyldodecyl] & 14.09 & 15.72 \\
\hline 7 & Diethyl Phthalate & 14.72 & 5.24 \\
\hline 8 & Octadecane, 3-ethyl-5-[2-ethylbutyl] & 14.99 & 3.25 \\
\hline 9 & $\begin{array}{l}\text { Cyclopropanebutanoic acid,2-||2-||2-|[2- } \\
\text { pentylcyclopropyl]methylcyclopropylmethylcyclopropylmethyl- } \\
\text { methyl ester }\end{array}$ & 15.20 & 2.96 \\
\hline 10 & Propanoic acid, 2-[3-acetotoxy-4,4,1,] 4-trimethylandrost-8-en-17-yl] & 15.86 & 6.76 \\
\hline 11 & $3,9 \beta ; 14,15$-Diepoxypregn-16-en-20-one, $3,11 \beta, 18$-triacetoxy & 17.03 & 12.44 \\
\hline 12 & 9,12,15-Octadecatrienoic acid,2,3-bis|[trimethylsilyl] oxy| propylester, & 18.09 & 7.13 \\
\hline 13 & Octadec-9-enoic acid icosyl ester & 18.46 & 7.07 \\
\hline 14 & Propanoic acid, 2-[3-acetoxy-4,4,] 4-trimethylandrost-8-en-17-yl & 19.26 & 4.42 \\
\hline 15 & D-Glucose,6-O- $\alpha$-D-galactopyranosyl, bis-O-[trimethylsilyl] & 24.41 & 3.62 \\
\hline
\end{tabular}

Antioxidant activity of the essential oil of aerial roots of Ficus elastica was evaluated by the scavenging activity of 2, 2-Diphenyl-1-picrylhydrazyl (DPPH) radical. The DPPH assay was performed by following the method of Epsin et al. (2000).

Table 2:- Antioxidant activity of essential oil from the aerial roots of Ficus elastica.

\begin{tabular}{|c|c|c|c|}
\hline $\begin{array}{c}\text { Serial } \\
\text { No. }\end{array}$ & $\begin{array}{c}\text { Concentration } \\
(\boldsymbol{\mu} \mathbf{L})\end{array}$ & $\begin{array}{c}\text { Absorbance } \\
(\mathbf{5 1 7} \mathbf{~ n m})\end{array}$ & \% Age Inhibition \\
\hline 1 & 20 & 1.104 & 6.44 \\
\hline 2 & 40 & 0.937 & 20.59 \\
\hline 3 & 60 & 0.687 & 41.77 \\
\hline 4 & 80 & 0.536 & 54.57 \\
\hline 5 & 100 & 0.460 & 61.01 \\
\hline
\end{tabular}

An antioxidant is a molecule that inhibits the oxidation of other molecules. Oxidation is a chemical reaction that can produce free radicals, leading to chain reactions that may damage cells. Antioxidants can assist in this oxidative stress. At concentrations of $20 \mu \mathrm{L}, 40 \mu \mathrm{L}, 60 \mu \mathrm{L}, 80 \mu \mathrm{L}$ and $100 \mu \mathrm{L}$ absorbencies were 1.104, 0.937, 0.687, 0.536 and 0.460 respectively, with percentage inhibition were $6.44 \%, 20.59 \%, 41.77 \%, 54.57 \%$, and $61.01 \%$ respectively at each concentration of extract and ascorbic acid considered as a standard with percentage inhibition was $92 \%$ at concentration of $100 \mu \mathrm{L}$. 


\section{Conclusion:-}

The essential oil from the aerial roots of ficus elastica was extracted through hydro-distillation and its GC-MS and antioxidant studied were carried out. Fifteen volatile constituents were identified and major constituents benzene, [1methyldodecyl], 9.96\%; benzene, [1-ethynundecyl] 14.14\%; 3,9 $\beta$, 14,15-di-epoxypregn-16-en-20-one 15.72\%,; benzene,[1-propyldecyl] 5.24\%; 9,12,15-octadecatrienoicacid $6.76 \%, 2,3$ bis[trimethylsilyl] 1-oxylpropylester 12.44\%, 9,12,15-octadecatrienoic acid,2,3-bis[trimethylsilyl-oxy propylester, 7.13\%, octadec-9-enoic acid icosyl ester $7.07 \%$ were in the essential oil of Ficus elastica aerial roots respectively. The essential oil extracted from the aerial roots of ficus elastica was slight yellow in color with $0.02 \%$ yield. Antioxidant activity of the essential oil was determined by using DPPH and ascorbic acid as standard. Maximum antioxidant activity $61.01 \%$ was observed at $100 \mu \mathrm{L}$. The antioxidant activity of the essential oil was concentration dependent.

\section{References:-}

1. Burkill L, H.1966. A Dictionary of the Economic Products of the Malay Peninsula. Kuala Lumpur, Malaysia: Ministry of Agriculture And Co-operative.1:1021; (1966).

2. Hamed MA. Beneficial effect of Ficus religiosa Linn. On high fat induced hypercholesterolemia in rats. Food Chem. 129:162-170; (2011).

3. Mousa O, Vuorela P, Kiviranta J, Abdel Wahab S,Hiltunen R,Vuorela H. Bioactivity of certain Egyptian Ficus species. J Ethnopharmacol.41:71-76; (1994).

4. Busari, A.O. Compendium of Plants Growing in Ogbomosho Area, Bayowa press, Nigeria (2001), p.102.

5. Abdel-Hameed ESS. Total phenolic content and free radical scavenging activity of certain Egyptian Ficus species leaf samples. Food chem. 114:1271-1277; (2009).

6. Kiem PV et al. Chemical constituents of the Ficus elastica leaves and their antioxidant activities. Bulletin of Korean Chemical society. 33(10):3461-3464; (2012).

7. Acharya, D. and A. Shrivastava, 2008. Indigenous herbal medicine: tribal formulations and traditional herbal practices 1st Edn. Avishkar publishers Distributors, Jaipur, India, ISBN-13.

8. Trivedi, P.S. Hinde and R.C. Sharma. "Preliminary photochemical and pharmacological studies on Ficus racemosa". Journal of Medicinal Research, 56: 1070-107; (1996).

9. Shoeb, M. 2006. Anticancer agents from medicinal plants. Bangladesh. J. Pharmacol, 1:35-41.

10. Manoj S. Mahajan, Vishal S. Gulecha, Rakesh A. Khandare, Aman B. Upaganlawar, Hemant H. Gangurde and Chandrashekhar D. Upasani. Anti-edematogenic and analgesic activities of ficus benghalensis. Journal of Nutrition, Pharmacology, Neurological Diseases, 2(2):100-104; (2012).

11. Gutterdgde J. Free radicals in disease process: A complication of cause and consequences. Free radical. Res. Comm.19, 141-158; (1995).

12. Tiwari A. Imbalance in antioxidant defense and human diseases. Multiple approach of natural antioxidant therapy Curr. Sci. 81.1179-1187; (2001)

13. Lobo V, Patil A, Phatak A, Chandra N. Free radicals, antioxidant and functional foods: impact on human health. Pharmacology Rev.4 (8):118-126; (2010).

14. ${ }^{\text {xiv }}$. Fatouma M, Abdoul-Latif, Nabil M, Prosper E, Adwa A, Samatar OD, Louis-Clement O, Ismael HNB, Mahmoudi HD. Antimicrobial and Antioxidant activities of essential oil and methanol extract of Matricaria chamomilla L. from Djibouti. J Med Plants Res. 5(9):1512-1517; (2011).

15. Jihua W, Liang X, Ling Y, Zhilong L, Ligang Z. Composition, Antibacterial and Antioxidant Activities of Essential Oils from Ligusticum sinense and al.ajeholense (Umbelliferae) from China. Rec Nat Prod. 5:314-318; (2011).

16. Epsin JC, Soler-Revas C, Wichers HJ. Charactization of the total free radical scavenging capacity of vegetable oil fractions using 2, 2diphenyl -1-picryhydrazyl radical. J. Agric. Food Chem. 48:648-56; (2000). 